\title{
Evidence of amelogenesis imperfecta in an early African Homo erectus
}

\author{
Uri Zilberman $^{\mathrm{a}, \mathrm{b}}$, Patricia $\mathrm{Smith}^{\mathrm{a}}$, Marcello Piperno ${ }^{\mathrm{c}}$, Silvana Condemi ${ }^{\mathrm{d}, *}$ \\ a Laboratory of Bio-anthropology and Ancient DNA, Hebrew University, Hadassah Faculty of Dental Medicine, Jerusalem, \\ P.O. Box 12272, Jerusalem, Israel \\ ${ }^{\mathrm{b}}$ Pedodontic Section, Dental Clinic for High Risk Patients, Barzilai Medical Center, Ashkelon, Israel \\ "Università di Roma "La Sapienza", Dipartimento di Scienze Storiche, Archeologiche e Antropologiche dell'Antichità Sezione di \\ Paletnologia, via Palestro 63, 00185 Rome, Italy \\ ${ }^{\mathrm{d}}$ Centre de Recherche Français de Jérusalem, CNRS-UMR 9930, 5 Shimshon Street, BP 547, 91004 Jerusalem, Israel
}

Received 25 November 2003; accepted 27 February 2004

\begin{abstract}
The teeth of the Homo erectus child (Garba IV) recovered from Melka Kunture Ethiopia and dated to $1.5 \mathrm{Ma}$ are characterized by generalized enamel dysplasia, reduced enamel radio-opacity, and severe attrition. This combination of features is found in a large group of hereditary, generalized enamel dysplasias known as amelogenesis imperfecta (AI). SEM studies carried out on epoxy replicas of teeth from the Garba IV child, confirmed that the defects noted were developmental and not due to diagenesis. The enamel prism arrangement is abnormal and there are deep vertical furrows lacking enamel on both buccal and lingual surfaces of all molars. The lesions differ from those characteristic of linear enamel hypoplasia that form discrete horizontal lesions or pits within otherwise normal enamel. We propose that the Garba IV child is the earliest example of AI and provides a link between palaeoanthropology and molecular biology in investigations of the evolutionary history of genetic disorders.

(C) 2004 Elsevier Ltd. All rights reserved.
\end{abstract}

Keywords: Homo erectus; Melka Kunture; Garba IV; Enamel dysplasia; Amelogenesis imperfecta

\section{Introduction}

The Garba IV child was found in level $\mathrm{E}$ at Melka Kunture, Ethiopia, during the 1981-82 excavations (D'Andrea et al., 2002; Kieffer et al.,

\footnotetext{
* Corresponding author

E-mail addresses: uri-z@inter.net.il (U. Zilberman), pat@cc.huji.ac.il (P.Smith), m.piperno@tin.it (M. Piperno), silvana.condemi@voila.fr (S. Condemi).
}

2002; Chavaillon and Piperno, in press). It has been dated to circa $1.5 \mathrm{Ma}$ and assigned to Homo erectus based on morphometric analysis of the teeth and mandibular corpus (Condemi, in press). The specimen comprises part of the right side of the mandible of a young child with the empty socket of the right deciduous canine, a heavily worn first deciduous molar (dm1), and an unworn second deciduous molar ( $\mathrm{dm} 2)$. The lingual surface of the mandibular corpus is broken, revealing part 

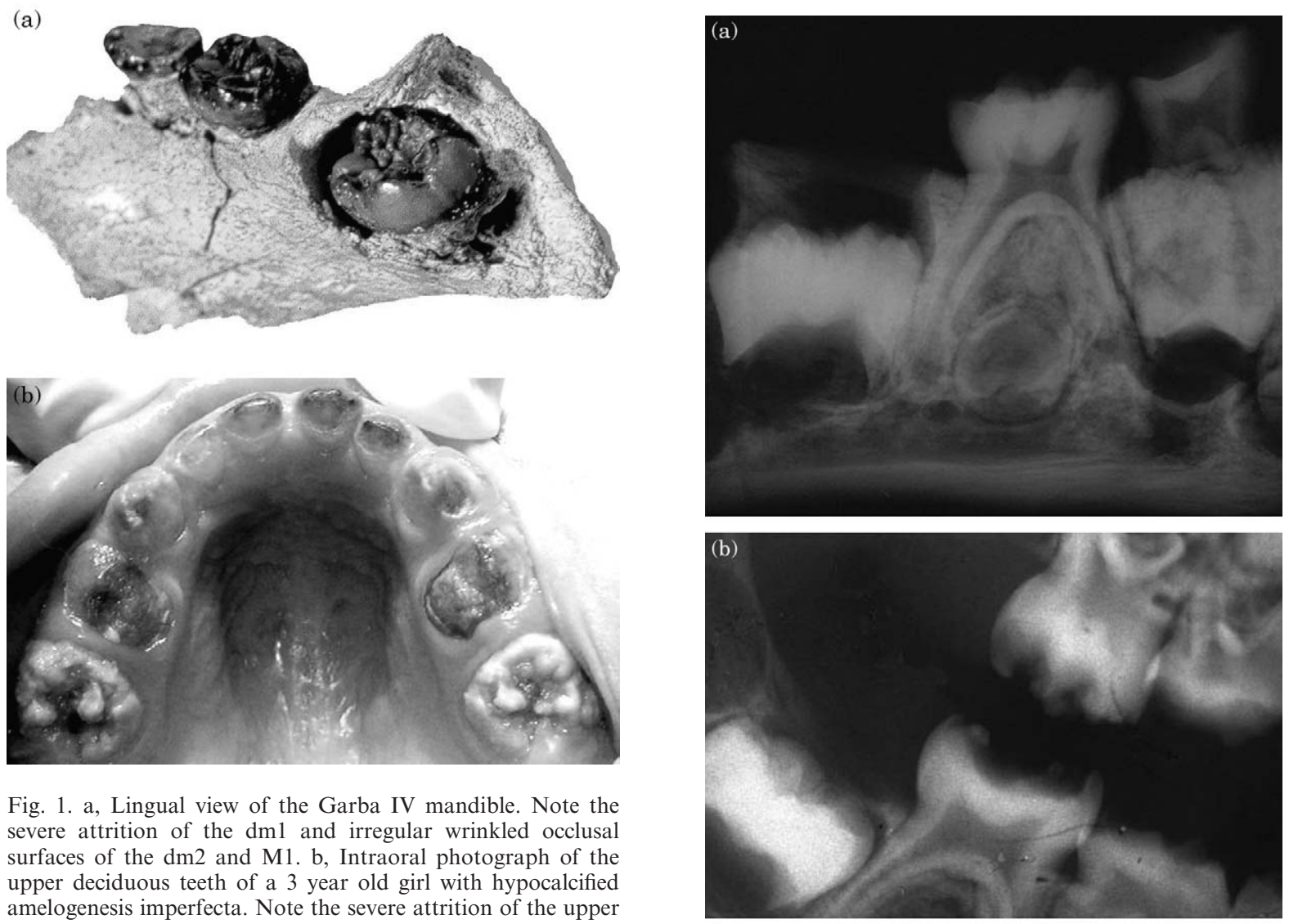

Fig. 1. a, Lingual view of the Garba IV mandible. Note the severe attrition of the $\mathrm{dm} 1$ and irregular wrinkled occlusal surfaces of the dm2 and M1. b, Intraoral photograph of the upper deciduous teeth of a 3 year old girl with hypocalcified amelogenesis imperfecta. Note the severe attrition of the upper incisors and $\mathrm{dm} 1$ resembling Garba IV $\mathrm{dm} 1$ and irregular occlusal morphology of the $\mathrm{dm} 2$.

of the developing permanent lateral incisor and canine anteriorly, and exposing the first permanent molar (M1) posteriorly. The crown of the M1 is complete, with about two mm of root, but is still deep in the jaw and covered by bone (Fig. 1a).

The roentgenograph of Garba IV (Fig. 2a) shows that the apices of the roots of the second deciduous molar are still patent, while crown formation of the permanent second premolar is just beginning. The stage of dental development suggests an age of approximately three years using modern standards of tooth development (Morrees et al., 1963; Liversidge et al., 1999) or two years assuming more precocious dental development in fossil hominids (Bromage and Dean, 1985; Dean et al., 1993; Smith, 1986). Whatever age estimate is used, the dm1 would have been in occlusion for a

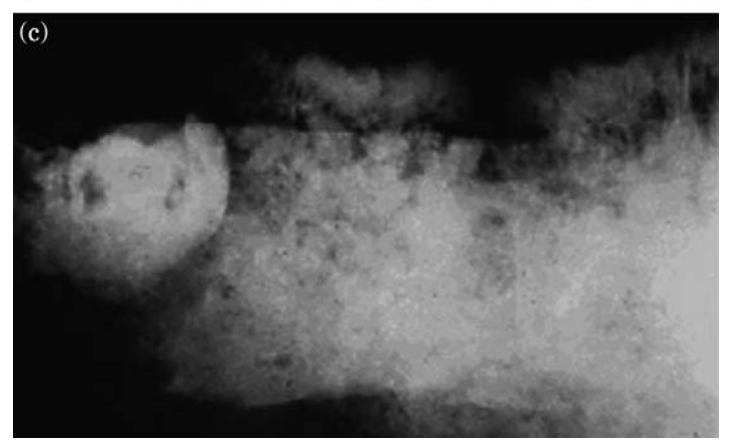

Fig. 2. a, Roentgenograph showing Garba IV. b, Roentgenograph showing clinical case of AI. c, Roentgenograph showing jaw of australopithecine child (SK 55b). Note the relative opacity of enamel, dentin, and bone and the low contrast between enamel and dentin in specimens in $2 \mathrm{a}$ and $2 \mathrm{~b}$ and the early loss of occlusal enamel, considered characteristic of hypocalcified AI. In both these individuals the M1 is still unerupted and separated from the occlusal surface by the roof of the bony crypt. They differ from the highly fossilized SK 55b specimen, where no internal morphology can be detected, and where despite the more advanced dental age, attrition of the deciduous teeth is less pronounced. 
Table 1

Comparison of the mesio-distal (MD) and bucco-lingual (BL) diameters of $\mathrm{dm} 1$ and $\mathrm{dm} 2$

\begin{tabular}{|c|c|c|c|c|}
\hline \multirow[t]{2}{*}{ Sample } & \multicolumn{2}{|c|}{ Dml } & \multicolumn{2}{|c|}{$\mathrm{Dm} 2$} \\
\hline & MD & $\mathrm{BL}$ & MD & $\mathrm{BL}$ \\
\hline Garba IV (Condemi, in press) & $(\mathbf{8 . 8 2})$ & (7.56) & 11.15 & 8.8 \\
\hline KNM ER 820 & 9.1 & 7.8 & 11.2 & 9.4 \\
\hline KNM ER 1477 & 11.9 & 9.2 & 14.3 & 11.8 \\
\hline KNM ER 1507 (Wood, 1991) & 8.8 & 6.8 & 11.7 & 9.3 \\
\hline Sinanthropus (Weidenreich, 1937) $N=7$ & & & 11.3 & 9.3 \\
\hline "Modern children" (Fearne and Brook, 1993) & $7.61 \pm 0.56$ & $6.69 \pm 0.47$ & $9.55 \pm 0.56$ & $8.86 \pm 0.49$ \\
\hline (Axelsson and Kirveskar, 1984 in Liversidge et al., 1999) & $7.90 \pm 0.46$ & $7.30 \pm 0.39$ & $10.03 \pm 0.56$ & $9.06 \pm 0.38$ \\
\hline
\end{tabular}

maximum of one and a half years and presumably the child had not been completely weaned. Despite this young age, half of the crown of the dm1 had already been worn away by attrition, indicating a major abnormality of the enamel.

Tooth size in the Garba child is similar to that of other Homo erectus specimens (Table 1), but the enamel is abnormal in appearance. All the Garba teeth show numerous irregularities of the enamel surface associated with defective enamel development. These include enamel pitting and vertical grooves or clefts on the buccal and lingual surfaces of all teeth. They differ from the localized defects seen in enamel hypoplasia that are associated with localized, time-related, developmental disturbances during enamel formation (Sarnat and Shour, 1941; Shafer et al., 1997). The unworn dm2 and M1 of Garba IV exhibit extensive wrinkling of the occlusal surfaces, as well as numerous additional marginal cuspules (Fig. 1a).

Tobias (1986) noted the presence of occlusal wrinkling in australopithecine molars and suggested that this might be an expression of hypoplasia. However, the condition as described by him was not associated with the presence of enamel defects elsewhere on the teeth. Linear enamel hypoplasia attributed to developmental stress has been recorded in most living and fossil primates and appears to have been fairly common in australopithecines and as other early hominids (White, 1978; Brunet et al., 2002; GuatelliSteinberg, 2003; Skinner and Newell, 2003). It occurs as discrete lesions within otherwise normal enamel and the location of the defects represents the timing of a developmental insult. Since the teeth develop at different times, the location of the defect varies from tooth to tooth. This differs from the condition seen in amelogenesis imperfecta (AI), where all teeth are affected in similar regions because of an inherited defect in enamel formation. This condition encompasses a broad spectrum of genetic diseases affecting enamel formation in both primary and permanent teeth and causing different combinations of enamel hypomaturation, hypomineralization and hypocalcification (Aldred et al., 2003). Amelogensis imperfecta in which hypomaturation and hypocalcification predominate is associated with difficulty in eating and drinking because of pain from even minor temperature changes or sweet and sour foods. The crowns of the teeth are rapidly worn away as the enamel crumbles, affecting the vertical dimensions of the face. While wrinkling and additional cuspules are not pathognomic of amelogenesis imperfecta, they are frequently found in children with this condition (Fig. 1b).

A more diagnostic characteristic is the roentgenographic appearance of the enamel in clinical cases of hypocalcified/hypomaturation AI (Witkop and Sauk, 1976; Witkop and Stewart, 1982). Normal mature enamel contains less than $4 \%$ of organic matrix. Bone and dentine contain well over $30 \%$ organic matrix, and thus they are far less radio-opaque than the enamel of normal teeth. The difference in ratio of organic to mineralized components also means that fossilization will affect the opacity of enamel far less than that of bone and dentine. In hypocalcified/hypomaturation AI, mineralization is impaired so that the opacity of the enamel is reduced and similar to that of 

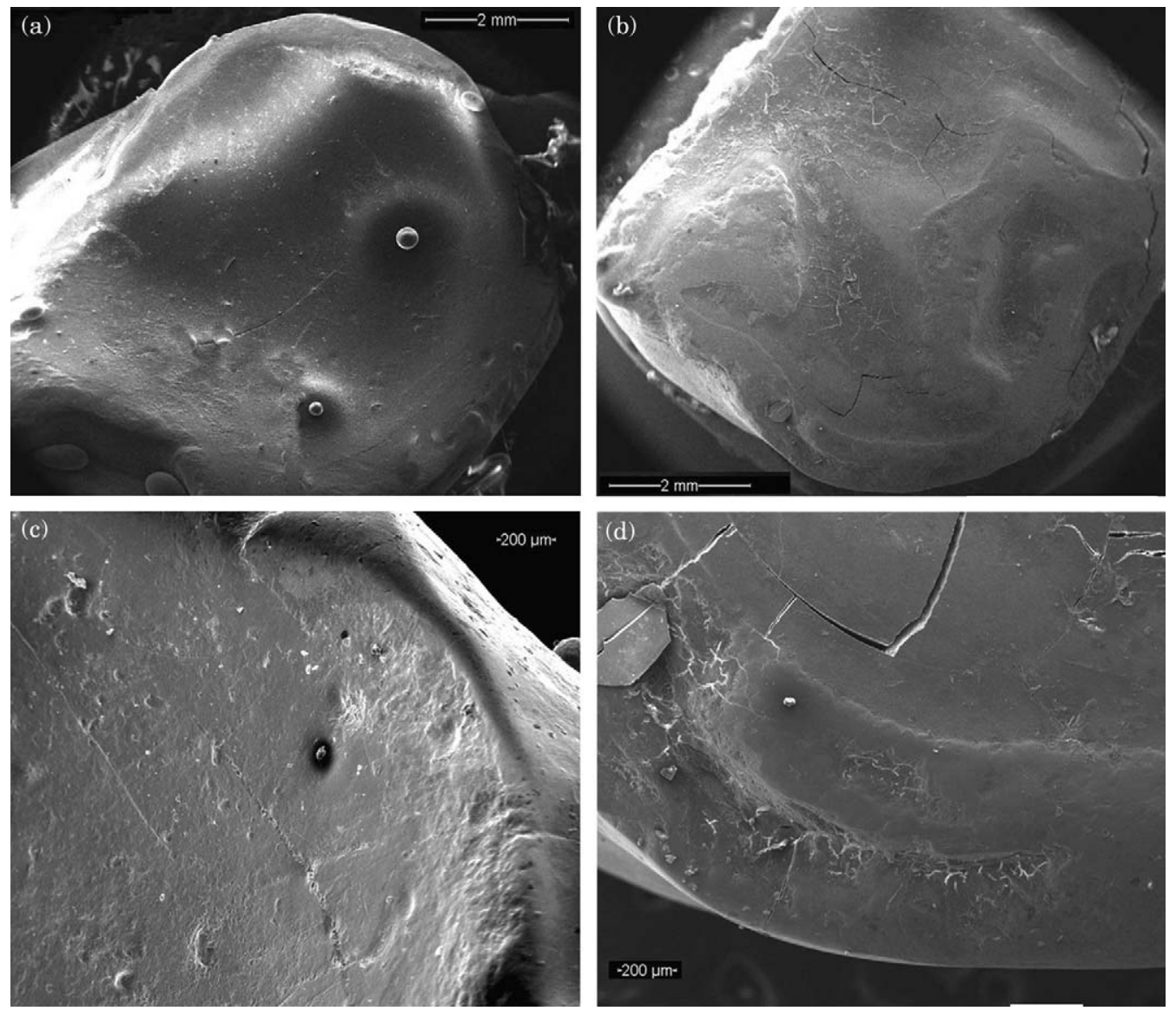

Fig. 3. a, SEM $\times 30$ of the worn occlusal surface of the dm1 in Garba IV. Note the smooth appearance of the surface and lack of definition of the enamel rim. b, SEM $\times 30$ of an exfoliated upper dm1 from a 10 year old child with normal enamel. Note the islands of enamel still present on the occlusal surface and the well differentiated enamel rim. c, SEM $\times 160$. Note the absence of differentiation between exposed dentin and the enamel rim in the Garba child, in contrast to the well defined enamel rim in the modern tooth $(\mathrm{d})$.

dentine and bone. As can be seen in Fig. 2a and b, the opacity of the enamel, dentine and bone in the Garba specimen is identical to that seen in modern cases of AI, with little differentiation between enamel and dentine, but excellent definition of the internal trabeculae of the bone, tooth roots and pulp cavities. This picture contrasts markedly with that seen in hypermineralized fossil jaws, such as the Swartkrans child SK55b shown in Fig. 2c, where little internal definition is visible in either the bone or teeth.

The combination of reduced radio-opacity, abnormally severe attrition, enamel defects and wrinkling in the Garba IV teeth was considered indicative of AI. In order to confirm this diagnosis we examined the ultrastructure of the enamel matrix from epoxy replicas under the SEM.

\section{Methods and materials}

Epoxy resin casts were made from silicone impressions of the Garba IV teeth. To minimize air bubbles, the silicone impression was placed in a vacuum chamber together with a fresh mixture of low viscosity epoxy resin for five minutes and then 

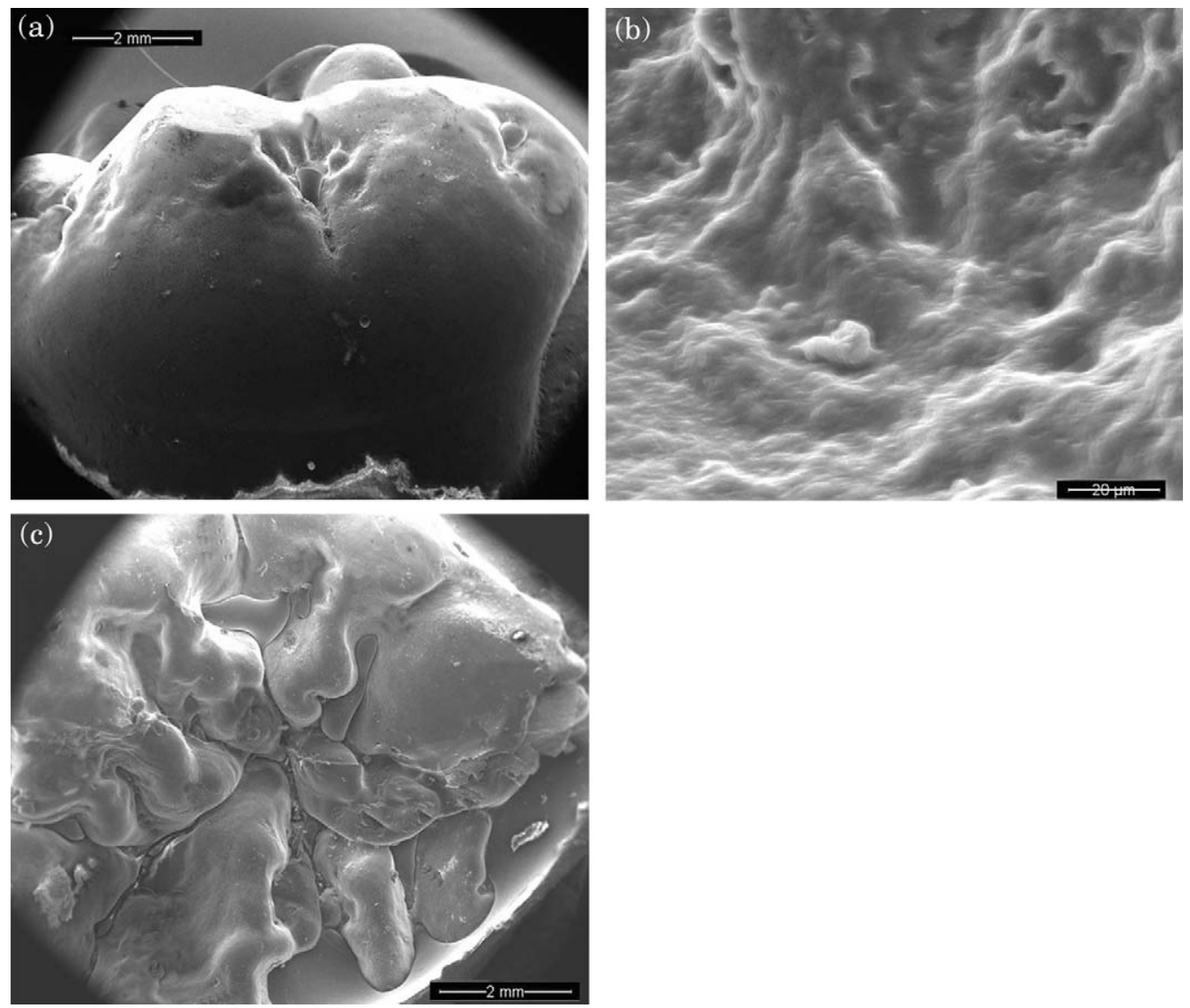

Fig. 4. SEM photographs of abnormal enamel in the dm2 and M1 of Garba IV. (a) shows the buccal aspect of the dm2 at magnifications of $\times 30$ and $b$ at $\times 2000$. Note the abnormal appearance of the wear on the buccal cusps of this newly erupted tooth (b) and the lack of regular prism form in the enamel. (c) shows the occlusal surface of the M1 at $\times 30$ and the abnormal enamel similar to that seen in the $\mathrm{dm} 2$.

filled with the resin and returned to the vacuum chamber for an additional five minutes. The epoxy was left overnight at room temperature to harden and then peeled away from the silicone impression. The casts were coated with colloidal gold and examined under a scanning electron microscope at magnifications ranging from $\times 30-\times 2000$, and compared with a normal exfoliated deciduous tooth with attrition into dentin (Figs. 3 and 4).

\section{Results}

The abraded occlusal surface of Garba dm1 (Fig. 3a and c) lacks the well defined enamel rim with sharp edges at the enamel-dentin margin seen in the normal tooth (Fig. 3b and d) and enamel and dentin show a similar smooth surface. The unworn surfaces of the $\mathrm{dm} 2$ and M1 are excessively wrinkled, with numerous small cuspules, especially on the occlusal margin, while the buccal fissures are deep and lack enamel at their bases (Fig. 4a and c). At high magnification, the enamel surface shows a mosaic appearance with numerous shallow pits identical to those reported in modern patients with AI (Fig. 4b). Taken in conjunction with the reduced enamel radio-opacity and severe attrition, the findings are indicative of amelogenesis imperfecta (AI) (MIM \#301200) (Witkop and Sauk, 1976; Backman et al., 1989). 


\section{Discussion}

Amelogenesis imperfecta has been classified into 14 different subtypes according to the clinical appearance of the enamel and mode of inheritance (Witkop and Sauk, 1976; Aldred et al., 2003). The prevalence of AI has been reported as 1:14,000 in the USA (Witkop and Sauk, 1976), 1:8000 in Israel (Chosak et al., 1979), 1:4000 in Sweden (Backman and Holmgren, 1988) and as high as 1:700 in the Vasterbotten county of Sweden (Backman and Holm, 1986). The X-linked form, AIH1, results from mutations in the $\mathrm{X}$-chromosome amelogenin gene (AMELX) and some 12 allelic mutations have already been reported (Hart et al., 2002a,b; $\mathrm{Hu}$ and Yamakoshi, 2003). A second locus for $\mathrm{X}$-linked recessive $\mathrm{AI}, \mathrm{AIH} 3$, has been mapped to chromosome Xq24-q27.1 (Aldred et al., 1992). Recent studies have revealed genotype-phenotype correlations with some of the X-linked mutations (Hart et al., 2000; Ravassipour et al., 2000; Li et al., 2003, Wright et al., 2003). The autosomaldominant forms of AI are the most prevalent, representing over $95 \%$ of all reported cases and have been shown to be genetically heterogenetic (Karrman et al., 1996). An autosomal-dominant, local hypoplastic form of AI (AIH2) has been mapped to a $4 \mathrm{Mb}$ region of human chromosome $4 q 11-q 21$ that encompasses the gene encoding the ameloblast-specific protein ameloblastin, AMBN (MacDougall et al., 1997). Identification of a locus on chromosome 2 q11 at which recessive AI and cone-rod dystrophy co-segregate has been reported (Downey et al., 2002). While AI is not in itself a fatal disease, the rapid attrition of teeth and consequent lack of ability to deal with even a soft diet that is characteristic of the condition must have been a serious handicap to survival in the past. Since skeletal remains of young children are relatively rare, it is not surprising that little evidence of this condition has been found in early hominids, even though the numerous mutations associated with AI suggests that it has a long evolutionary history despite the associated handicap.

We propose that the enamel defects, reduced radio-opacity, severe attrition relative to the young age of the specimen, together with the location and type of hypoplastic defects seen on the SEM images indicate that the Garba IV child is an early example of AI. While we may never be able to recover DNA from hominins dating to this early period, improved diagnostic techniques are helping us to obtain more precise information about structure and function. This study has provided evidence of a direct genetic link between Homo erectus and modern humans. It enables us to test some of the models for mutation rates that have been put forward by molecular biologists and substantiates modern genetic studies that indicate a long evolutionary history for amelogenesis imperfecta.

\section{Acknowledgements}

This study was supported in part by a grant from the Israel Sciences Foundation no.032-5302. We extend our special thanks to the National Museum in Addis Ababa and to Dr. Yirka Zelalem of the Bethzatha Medical Center for his help with the radiographs of Garba IV.

\section{References}

Aldred, M.J., Crawford, P.J., Roberts, E., Gillespie, C.M., Thomas, N.S., Fenton, I., Sandkuiji, L.A., Harper, P.S., 1992. Genetic heterogeneity in X-linked amelogenesis imperfecta. Genomics 14, 567-573.

Aldred, M.J., Savarirayan, R., Crawford, P.J.M., 2003. Amelogenesis imperfecta: a classification and catalogue for the 21st century. Oral and Maxillofacial Pathology 9, 19-23.

Axelsson, G., Kirveskar, P., 1984. Crown size of deciduous teeth in Icelanders. Acta Odont. Scand. 42, 339.

Backman, B., Holmgren, G., 1988. Amelogenesis imperfecta: a genetic study. Hum. Hered. 38, 189-206.

Backman, B., Holm, A.K., 1986. Amelogenesis imperfecta: prevalence and incidence in a northern Swedish country. Comm. Dent. Oral Epidemiol. 14, 43-47.

Backman, B., Anneroth, G., Horstedt, P., 1989. Amelogenesis imperfecta: a scanning electron microscopic and microradiographic study. J. Oral Pathol. Med. 18, 140-145.

Bromage, T.G., Dean, M.C., 1985. Re-evaluation of the age at death of immature fossil hominids. Nature 317, 525-527.

Brunet, M., Fronty, P., Sapanet, M., de Bonis, L., Viriot, L., 2002. Enamel hypoplasia in a pliocene hominid from Chad. Connective Tissue Res. 43, 94-97.

Chavaillon, J., Piperno, M. (Eds.), in press. Studies on Melka Kunture. The Oldowan and the Developed Oldowan. Origines, Instituto Italiano di Preistoria e Protostoria, Firenze. 
Chosak, A., Eidelman, E., Wisotski, I., Cohen, T., 1979. Amelogenesis imperfecta among Israeli Jews and the description of a new type of local hypoplastic autosomal recessive amelogenesis imperfecta. Oral Surg. Oral Med. Oral Pathol. 47, 148-156.

Condemi, S., in press. Studies on Melka Kunture. The Oldowan and the Developed Oldowan. In: Chavaillon, J., Piperno, M. (Eds.), Origines. Instituto Italiano di Preistoria e Protostoria, Firenze, pp. 60-78.

D'Andrea, A., Gallotti, R., Piperno, M., 2002. Taphonomic interpretation of the Developed Oldowan site of Garba IV (Melka Kunture, Ethiopia) through a GIS application. Antiquity 76, 991-1001.

Dean, M.C., Beynon, A.D., Thackeray, J.F., Macho, G.A., 1993. Histological reconstruction of dental development and age at death of a juvenile Paranthropus robustus specimen, SK 63, from Swatkrans, South Africa. Am. J. Phys. Anthrop. 91, 401-419.

Downey, L.M. et al., 2002. Identification of a locus on chromosome $2 \mathrm{q} 11$ at which recessive amelogenesis imperfecta and cone-rod dystrophy cosegregate. Eur. J. Hum. Genet. 10, 865-869.

Fearne, J.M., Brook, A.B., 1993. Small primary tooth-crown size in low birth weight children. Early Hum. Dev. 33, $81-90$.

Guatelli-Steinberg, D., 2003. Macroscopic and microscopic analyses of linear enamel hypoplasia in Plio-Pleistocene South African hominids with respect to aspects of enamel development and morphology. Am. J. Phys. Anthrop. 120, 309-322.

Hart, P.S., Hart, T.C., Gibson, C., Wright, J.T., 2000. Mutational analysis of $\mathrm{X}$-linked amelogenesis imperfecta in multiple families. Arch. Oral Biol. 45, 79-86.

Hart, P.S., Hart, T.C., Simmer, J.P., Wright, J.T., 2002a. A nomenclature for X-linked amelogenesis imperfecta. Arch. Oral Biol. 47, 255-260.

Hart, P.S., Aldred, M.J., Crawford, P.J., Wright, N.J., Hart, T.C., Wright, J.T., 2002b. Amelogenesis imperfecta phenotype-genotype correlations with two amelogenin gene mutations. Arch Oral Biol. 47, 261-265.

Hu, J.C., Yamakoshi, Y., 2003. Enamelin and autosomaldominant amelogenesis imperfecta. Crit. Rev. Oral Biol. Med. 14, 387-398.

Karrman, C., Backman, B., Holmgren, G., Forsman, K., 1996. Genetic heterogeneity of autosomal dominant amelogenesis imperfecta: demonstrated by its exclusion from the AIH2 region on human chromosome 4q. Arch. Oral Biol. 41, 893-900.

Kieffer, G., Raynal, J.-P., Bardin, G., 2002. Cadre structural et volcanologiques des sites du Paléolithique ancien de Melka Kunture (Awash, Ethiopie): premiers resultats. In: Raynal, J.-P., Albore-Livadie, C., Piperno, M. (Eds.), Hommes et volcans. De l'eruption a l'objet, Les dossiers de
l'Archæo-Logis, 2, Proceedings Symposium 15.2, XIV UISPP Congress, Liege, pp. 77-92.

Li, W., Gao, C., Yan, Y., DenBestan, P., 2003. X-linked amelogenesis imperfecta may result from decrease formation of tyrosine rich amelogenin peptide (TRAP). Arch. Oral Biol. 48, 177-183.

Liversidge, H.M., Speechly, T., Hector, M.P., 1999. Dental maturation in British children: are Demirjian's standards applicable? Int. J. Paediatr. Dent. 9, 263-269.

MacDougall, M. et al., 1997. Ameloblastin gene (AMBN) maps within the critical region for autosomal dominant amelogenesis imperfecta at chromosome $4 \mathrm{q} 21$. Genomics 41 , $115-118$.

Morrees, C.F.A., Fanning, E.A., Hunt, E.E. Jr, 1963. Age variation of formation stages for ten permanent teeth. J. Dent. Res. 42, 1490-1502.

Ravassipour, D.B., Hart, P.S., Hart, T.C., Ritter, A.V., Yamauchi, M., Gibson, C., Wright, J.T., 2000. Unique enamel phenotype associated with amelogenin gene (AMELX) codon point mutation. J. Dent. Res. 79, 1476-1481.

Sarnat, G.B., Shour, I., 1941. Enamel hypoplasia (chronologic enamel aplasia) in relation to systemic disease: a chronologic, morphologic and etiologic classification. J. Am. Dent. Assoc. 28, 67-74.

Shafer, W.G., Hine, M.G., Levy, B.M. (Eds.), 1997. A Textbook of Oral Pathology. Saunders, Philadelphia.

Skinner, M.F., Newell, E.A., 2003. Localized hypoplasia of the primary canine in bonobos, orangutans and gibbons. Am. J. Phys. Anthrop. 120, 61-72.

Smith, B.H., 1986. Dental development in Australopithecus and early homo. Nature 323, 327-330.

Tobias, P.V. 1986. Enamel crenulations and wrinkles on hominid molar teeth: are crenulations an expression of enamel hypoplasia? In: Novotny, V.V., Mizerová, A. (Eds.), Fossil Man. New Facts, New Ideas. Papers in Honor of Jelínek's Life Anniversary. Antrhopos (Brno) 23, pp. 66-77.

Weidenreich F., 1937. The dentition of Sinanthropus pekinensis: a comparative odontography of the hominids. Paleontologia Sinica, Series D, I, pp. 1-180.

Witkop, C.J., Sauk, J.J., 1976. In: Stewart, R.E., Prescott, G.H. (Eds.), Oral Facial Genetics. Mosby, St Louis, pp. 151-226.

Witkop, C.J. Jr, Stewart, R.E., 1982. In: Stewart, R.E., Barber, T.K., Troutman, K.C., Wei, S.H.Y. (Eds.), Pediatric Dentistry. Mosby, St Louis, pp. 110-117.

White, T.D., 1978. Early hominid enamel hypoplasia. Am. J. Phys. Anthrop. 49, 79-84.

Wood, B., 1991, Koobi Fora Research Project, Vol. 4: Hominid Cranial Remains. Clarendon Press, Oxford.

Wright, J.T., Hart, P.S., Aldred, M.J., Seow, K., Crawford, P.J., Hong, S.P., Gibson, C.W., Hart, T.C., 2003. Relationship of phenotype and genotype in X-linked amelogenesis imperfecta. Con. Tis. Res. 44(Suppl.), 72-78. 